\title{
STUDIES ON NEOTROPICAL POMPILIDAE (HYMENOPTERA) V. AUSTROCHARES BANKS*
}

\author{
By Howard E. Evans \\ Museum of Comparative Zoology
}

In the previous paper of this series (Evans, I968), I described several cases of dual sex-limited mimicry in the genus Chirodamus and mentioned that certain species of Austrochares also exhibit this phenomenon. Since the situation is somewhat different from that prevailing in Chirodamus, and since I had previously stated (1966) that Austrochares as originally conceived by Banks (1947) was diphyletic, it seems desirable to clarify this matter further. Austrochares was based upon gastricus Spinola and properly includes this species and four others; this genus is closely related to Episyron, Poecilopompilus, and Sericopompilus. The remaining species placed in the genus by Banks are much more closely related to Anoplius and Pompilus and are properly assignable to the genus Dicranoplius Haupt (1950). I hope to review Dicranoplius in the next paper of this series.

The cases of dual mimicry occur in Austrochares as here restricted, and not in Dicranoplius. As in the instances of dual mimicry I described in Chirodamus, the females belong to a Müllerian mimetic complex principally involving solitary wasps, while the males appear to be Batesian elements in a large mimetic complex centering around certain social wasps. Both complexes happen to be different than in Chirodamus, but I assume that similar selection pressures have been operative. The females evidently spend most of their time on the ground hunting for spiders and have evolved a color pattern of black and rufous like that of a great many solitary wasps occurring in the same situations (e.g. Dicranoplius satanus) (Figs. 2, 4), while the males spend most of their time flying in low vegetation in company with the workers of various social Vespidae.

In this instance the model of the males is undoubtedly Polybia occidentalis Olivier and its complex of sibling species (partially resolved by Richards, I95 I). Bequaert (1944) speaks of occidentalis (that is, of the complex) as "the most common social wasp of tropical America". The males are black except for conspicuous yellow spots on the scutellum and metanotum, a yellow margin on the pronotum,

*Manuscript received by the editor November 25, 1968 


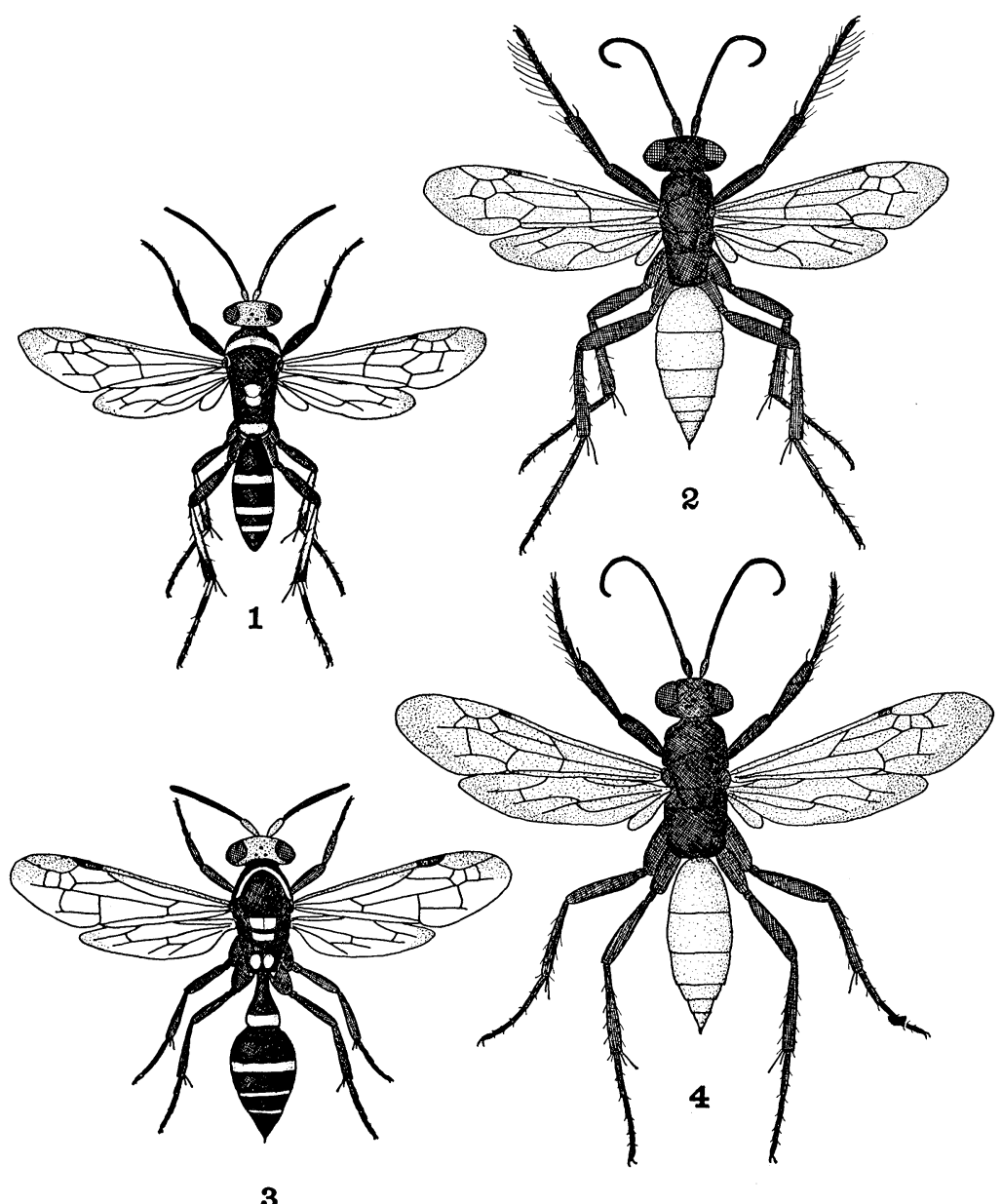

Figures 1-4. Dual mimicry in Austrochares gastricus (Spinola): male and female in upper two figures, models in lower two figures. Fig. 1. A. gastricus male, Potrerillos, Mendoza, Argentina. Fig. 2. A. gastricus female, same locality. Fig. 3. Polybia parvula ruficeps Schrottky (Vespidae), female, La Rioja, Argentina. Fig. 4. Dicranoplius satanus (Holmberg) (Pompilidae), female, Cacheuta, Mendoza, Argentina. 
and transverse yellow bands on the abdomen (both models and mimics). Males of Austrochares gastricus in western Argentina also often have a partially or wholly rufous head (Fig. I), as in ruficeps Schrottky (Fig. 3), a member of the Polybia occidentalis complex which is common in that area. Still others have reduced pronotal and abdominal banding, as in scutellaris White, another member of this complex. Since various members of the occidentalis complex range all the way from Mexico to Patagonia, the complex may provide models for several species of Austrochares of more restricted range, and it appears that gastricus, at least, is polymorphic in color, using at least three members of the complex as models. Similar color patterns also occur in several species of Mischocyttarus and other social Vespidae. Obviously the problem is complex and worthy of much more study.

One of the most interesting aspects of mimicry in Austrochares is that only three of the five species have males which share the color pattern of social wasps; the remaining two are not sexually dimorphic in color. The two which are not dual mimics (elsinore and chilensis) occur in areas where members of the Polybia occidentalis complex are rare or absent (coastal Peru and Chile), while the three species which have mimetic males occur in areas of great abundance of occidentalis and related species. Actually only mexicanus and gastricus are known to be dual mimics, since exiguus Banks is known only from the type male. However, the close resemblance of this male to that of mexicanus and gastricus leads me to believe that the female will also prove to be similar to those species.

The case of Austrochares gastricus is especially interesting. This species has been regarded by Banks and others as occurring in both Argentina and Chile, but several authors have remarked that no Argentinian males have ever been found (although Chilean males are common enough). Only Brèthes (1913) hit upon the truth when he suggested that Holmberg's "male" species autrani might go with gastricus or a similarly colored species. I regard autrani as in fact the male of gastricus, a species occurring east of the Andes and showing strong mimetic dimorphism. The Chilean "gastricus" is here described as a new species, which is not dimorphic. The association of autrani with gastricus is supported by the fact that both sexes bear a strong resemblance to mexicanus, the two sexes of which were associated several years ago. Banks (I947) assigned the males of two of the species of Austrochares to "Batazonus", i.e., Poecilopompilus, but they do not belong there. Most species of Poecilopompilus 
mimic social wasps (in both sexes), but none appear to have Polybia occidentalis as a model.

It is possible that the all-black species elsinore is the most primitive member of this complex, for it is remarkably like an Episyron, differing chiefly in the total absence of squamose pubescence. On the other hand, it may be a species derived from a chilensis-like or gastricus-like ancestor, the black color of both sexes being selected for within its range (arid portions of coastal Peru) because of the absence of the usual models and the presence of all-black models in this area.

In summary, the coloration of the five species of this genus may tentatively be described as mimetic in the following manner:

$\begin{array}{lll}\begin{array}{l}\text { Wholly black } \\ \text { (like many }\end{array} & \begin{array}{l}\text { Black with } \\ \text { rufous abdomen } \\ \text { (like many }\end{array} & \begin{array}{l}\text { Black and } \\ \text { yellow (re- } \\ \text { sembling }\end{array} \\ & \text { solitary wasps } & \begin{array}{l}\text { Polybia } \\ \text { occidentalis } \\ \text { complex) }\end{array}\end{array}$

elsinore ................Females \& males

chilensis ................................................Females \& males

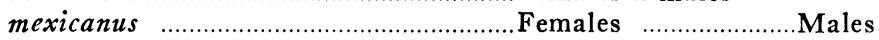

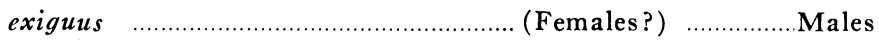

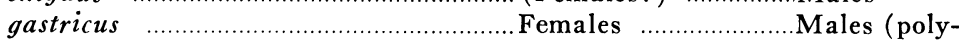

morphic, re-

sembling

several mem-

bers of complex)

Genus austrochares Banks

Austrochares Banks, 1947, p. 423 (type species: Pompilus gastricus Spinola, original designation). - Evans, 1966, p. 200.

Generic characters. - Clypeus not or barely wider than lower interocular distance, apical margin truncate, upper margin strongly sinuate, with notches at the anterior tentorial pits; eyes of female strongly convergent on the upper third; ocellar triangle broad and rather flat. Scutellum and central part of metanotum convex; postnotum constricted medially and before the spiracles, slightly arcuately expanded between these constrictions; legs strongly spinose, front tibiae spinose for most of their length, front tarsus of female with a strong pecten; claws of both sexes bifid, inner ray truncate; pulvillar pad small, the comb weakly developed. Wings as figured by Evans, I966, fig. I6, the second recurrent vein arising more than half way from base of subdiscoidal vein to wing margin, anal vein of hind wing meeting media at or slightly beyond origin of cubitus. Male genitalia with the basal hooklets double, parameres slender, aedoeagus with a few small setae (genitalia differing in no important 
ways from those of Poecilopompilus and Episyron). Female with only a few thin setae at apex of abdomen.

Key to Species

Females

I. Wholly black, pubescence mostly dark and with strong bluish reflections; spines of tarsal comb very short (Peru)

elsinore Banks

Abdomen rufous, pubescence brownish to silvery, without strong bluish reflections; spines of tarsal comb very long

\section{2}

2. Hind tibiae and tarsi and middle tarsi mostly rufous; entire body covered with conspicuous silvery pubescence (Mexico)

mexicanus Dreisbach

Middle and hing legs wholly black; pubescence finer and over most of head and thorax somewhat brownish ..................... 3

3. Head rather thick, the temples, as seen from above, about as wide as the eyes (Fig. 8) (Chile) ……...... chilensis n. sp. Head thin, the temples not nearly as wide as the eyes (Fig. 9) (Argentina, southern Brazil) gastricus (Spinola)

\section{Males}

I. Coloration similar to that of female, the head and thorax black, the abdomen either black or rufous; legs black 2 Coloration very different from that of female, black or black and ferruginous, scutellum and metanotum spotted with yellow, and usually with other yellow markings on the body; legs annulated with yellow

2. Abdomen black; slope of propodeum low and even; digiti with short setae (Fig. 7) (Peru) elsinore Banks

Abdomen rufous; propodeum, in lateral view, strongly convex, with a somewhat flattened declivity, digiti with longer setae (Fig. 5) chilensis n. sp.

3. Tibiae black, more or less marked with yellow; clypeus black, rarely yellow on extreme sides; a robust species (Argentina and southern Brazil) gastricus (Spinola)

Tibiae mainly rufous, with yellow markings; clypeus broadly yellow on the sides; more slender species

4. Posterior rim of propodeum and a broad band on first tergite yellow; digiti of genitalia somewhat acute apically; length $6.5 \mathrm{~mm}$, fore wing $5.5 \mathrm{~mm}$ (northern Brazil)

exiguus (Banks)

Posterior rim of propodeum and first abdominal tergite mostly or wholly black; digiti rounded apically; length 7 to $9.5 \mathrm{~mm}$, fore wing $6.5-8.5 \mathrm{~mm}$ (Mexico) mexicanus Dreisbach 


\section{Austrochares elsinore Banks}

Austrochares elsinore Banks, 1947, p. 426 [Type: + , PERU: Lima, 21 May 1920 (Cornell Univ. Exped.) (Cornell Univ., No. 2547)].

Female. - Length IO-I I $\mathrm{mm}$; fore wing 9-10 mm. Black, except inner orbits with a small pale spot and outer orbits with a pale streak; pubescence with strong bluish reflections; propodeum with a few short hairs on the sides; wings moderately fumose, violaceous. Clypeus $2.2 \times$ as wide as high; middle interocular distance $.63 \times$ transfacial distance; upper interocular distance $.73 \times$ lower interocular distance, the vertex arched gently above the eye tops; postocellar line slightly exceeding ocello-ocular line; antennae slender, third segment subequal to upper interocular distance. Propodeum with the slope low, posterior third with a flat declivity; fore tarsus with three slender comb-spines, the apical one .5-.7 $\times$ as long as second segment. Anal vein of hind wing reaching media well beyond origin of cubitus; third submarginal cell of fore wing trapezoidal, narrowed by about half above.

Male. - Length $8 \mathrm{~mm}$; fore wing $7 \mathrm{~mm}$. Color of body, wings, and pubescence as in female except marks on inner and outer orbits larger and apical tergite with a small white spot; propodeum with a few inconspicuous short hairs. Clypeus $2.0 \times$ as wide as high; middle interocular distance $.62 \times$ transfacial distance; inner orbits strongly divergent from bottom, then abruptly convergent on upper third, upper and lower interocular distances equal; ocello-ocular line slightly exceeding postocellar line; antennae slender, segment three 2.I $X$ as long as wide, .6 $\times$ upper interocular distance. Slope of propodeum low and even; wing venation as in female. Abdomen slender, fusiform; genitalia with the parameres nearly straight, parapenial lobes very slender, curved, digiti clothed with very short setae (Fig. 7).

Distribution. - Known only from Lima, Peru. The male bears data identical to those of the type except that it was collected 8 May I920; it is labeled as a paratype, but it is not really a paratype, as Banks makes no mention of this specimen. A female paratype [Mus. Comp. Zool.] also bears the same data except that it was collected 2 I May I920.

Austrochares chilensis new species

Pompilus gastricus Spinola, 1851, p. 380 [in part].-Reed, 1894, pp. 611, 615. - Banks, 1947, p. 424 [in part].

Holotype. - + chile: Pudahuel, Prov. Santiago, 29 Jan. I95I (L. Peña) [Mus. Comp. Zool., no. 3i678].

Description of female type. - Length $12 \mathrm{~mm}$; fore wing $9.5 \mathrm{~mm}$. 


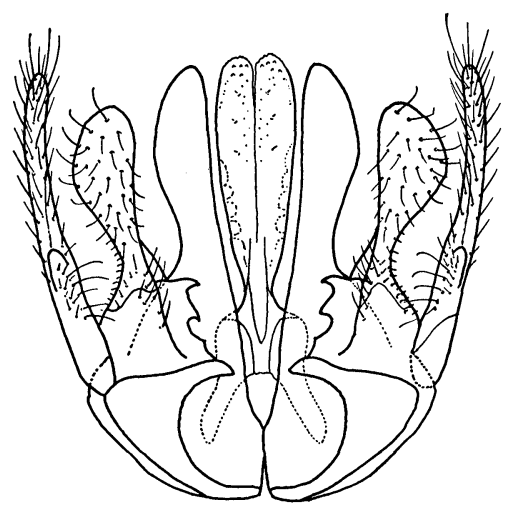

5

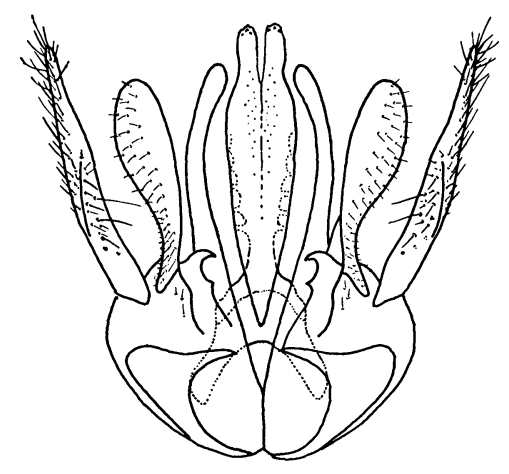

7

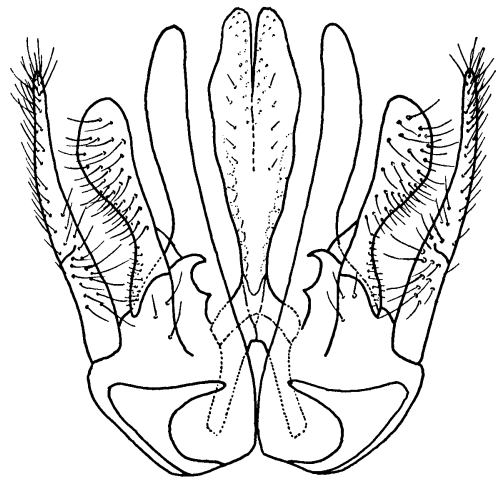

6

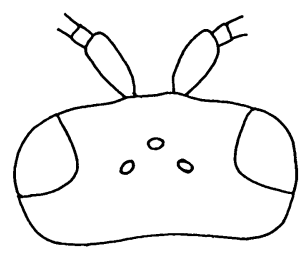

8

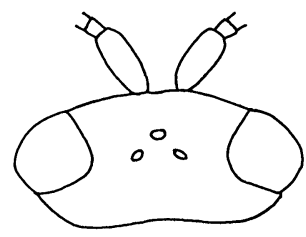

9

Fig. 5. Male genitalia of Austrochares chilensis n. sp., ventral aspect. Fig. 6. Same of $A$. gastricus (Spinola). Fig. 7. Same of $A$. elsinore Banks. Fig. 8. Head of female $A$. chilensis n. sp., dorsal aspect. Fig. 9. Head of female $A$. gastricus (Spinola), dorsal aspect.

Head, thorax, legs, and antennae black, abdomen wholly ferruginous; wings lightly infuscated except fore wing more clouded on apical two-thirds and especially in a band along outer margin; pubescence of head and thorax dark, somewhat violaceous; propodeum with numerous rather long setae. Clypeus $2.5 \times$ as wide as high; middle interocular distance $.63 \times$ transfacial distance; upper interocular distance $.80 \times$ lower interocular, vertex arched above eye tops; postocellar and ocello-ocular lines subequal; head thick behind eyes, 
the temples, in dorsal view, nearly as wide as the eyes (Fig. 8). Antennae slender, segment three $.75 \times$ upper interocular distance. Propodeum convex, with a somewhat flattened declivity on posterior half; front tarsus with a comb of long, somewhat flattened spines, four on the basitarsus, the apical one I.7 $\times$ as long as second tarsal segment. Anal and cubital veins of hind wing interstitial; third submarginal cell of fore wing narrowed by two-thirds above.

Allotype. $-\sigma^{x}$, same data as type $[\mathrm{MCZ}]$.

Description of male allotype. - Length $9 \mathrm{~mm}$; fore wing $8 \mathrm{~mm}$. Color exactly as in female, pubescence and pilosity also as in that sex. Clypeus $2.2 \times$ as wide as high; middle interocular distance $.62 \times$ transfacial distance; upper interocular distance subequal to lower interocular distance; postocellar and ocello-ocular lines subequal. Antennae slender, segment three $2.5 \times$ as long as wide, about half as long as upper interocular distance. Propodeum strongly convex and with a somewhat flattened declivity, as in female; wing venation also as in that sex. Abdomen robust, slope of the first tergite higher than in elsinore; subgenital plate tectiform, broadly rounded apically; genitalia as shown in figure 5, differing from those of gastricus in the shape of the aedoeagus and in the slightly broader parapenial lobes.

Paratypes. - chile: I ㅇ, Santiago [Mus. Comp. Zool]; 2 우, I $\sigma^{x}$, Valparaiso, Dec., Jan. (Herbst, Faz) [Mus. Comp. Zool., Cornell Univ.]; $9 \sigma^{x} \sigma^{x}$, Hacienda Illapel, Coquimbo, Nov. (Peña) [Mus. Comp. Zool.]; i +, Angol, Dec. [Cornell Univ.]; $30^{\star} 0^{\star}$, Los Angeles, Bio Bio, Feb. [Mich. State Univ.].

Variation. - The available females vary but slightly in size (fore wing 9.5 - I I mm). In one specimen the clypeus is only $2.3 \times$ as wide as high, and in two there is a small fifth comb-spine on the basitarsus. The males also show but little variation in size (fore wing 8-1O mm) and no noteworthy variation in color or other features.

Remarks. - There can be no question that the name gastricus properly applies to the species occurring east of the Andes; although Spinola describes the species in the Historia de Chile, he remarks as follows: "El tipo de esta especie es una hembra del Brasil que M. Klug me habia enviado con el nombre que le he conservado. Los individuos de Chile que le he juntado, me han parecido enteramente semejantes a este tipo por su talla, por sus formas y por sus colores."

Professor U. Parenti, of the Museum at the Universita di Torino, Italy, has sent me two females from the Spinola collection which 
presumably represent those which Spinola had before him. One, labelled simply "Brasil", is here designated lectotype of gastricus on the basis of the remarks quoted above. Since there are no specimens in the Berlin Museum clearly from the Klug or Spinola collections, it seems probable that this is the true type. The second specimen, labeled "Chili, Gay" has broad temples and clearly belongs to chilensis n. sp., while the female from Brazil has narrow temples characteristic of gastricus as here interpreted.

\section{Austrochares gastricus (Spinola)}

Pompilus gastricus Spinola, 1851, p. 380 [Type: $\$$, BRAZIL (no further data) (Univ. Torino; see comments above)]. - Taschenberg, 1869, p. 65 [ㅇ, Mendoza, Argentina]. - Burmeister, 1872, p. 238. - Holmberg, 1881, p. 143 [웅 $\hat{o}$ misidentified]. - Berg, 1881, p. 71 [우, Carhué, La Pampa, Argentina]. - Brèthes, 1909, p. 460 [Mendoza, Argentina].

Pompilus autrani Holmberg, 1903, p. 499 [ô, Chaco, Argentina]. New synonymy.

Pompilus annuliventris Brèthes, 1909, p. 460 [ $\hat{o}$, Chacras de Coria, Potrerillos, Argentina]. Synonymy with autrani by Brèthes, 1913.

Psammochares autrani: Brèthes, 1913, p. 117 [ $\hat{o}$, Mendoza, Argentina]. Batazonus autrani: Banks, 1947, p. 381 [ô, Mendoza, Argentina].

Austrochares gastricus: Banks, 1947, p. 434 [in part; $q$ o from Mendoza and San Ignacio, Argentina].

Female. - Length 8-12 mm; fore wing 7-I I mm. Body color as in chilensis; wings rather heavily infuscated; pubescence of head and thorax brownish, somewhat violaceous, sometimes somewhat silvery on front; propodeum with erect setae which may be dark or rather pale. Clypeus 2.3-2.5 $X$ as wide as high; upper interocular distance $.70-.80 \times$ lower interocular; postocellar and ocello-ocular lines subequal; third antennal segment .78-.90 $\times$ upper interocular distance; head distinctly thinner than in chilensis, as seen from above contracted immediately behind eyes, the temples not nearly as wide as the eyes. Features of thorax and abdomen as in chilensis. (Figs. 2, 9).

Male. - Length 7-9.5 mm; fore wing 6.5-9 mm. Body black, with pale yellow markings as follows: inner and outer orbits, scape beneath, posterior margin of pronotum, center of scutellum and metanotum, sometimes a band on propodeum, bands on tergites 2-4 and often an interrupted band on I, spots on apical two tergites; middle and hind tibiae with pale streaks, all spurs pale, and all tarsi annulated with pale yellow; flagellum ferruginous, especially below, and specimens from western Argentina (Salta, Mendoza) often with the head partly or wholly ferruginous; wings hyaline, most specimens with a dark tip on the fore wing; pubescence mostly silvery, erect setae on propodeum and elsewhere pale (Fig. I). Clypeus i.9-2.0 
$X$ as wide as high; third antennal segment 2.0-2.4 $X$ as long as wide; other head features as in chilensis. Propodeum short, strongly convex in profile. Subgenital plate similar to that of chilensis; genitalia as shown in figure 6 .

Distribution. - Argentina south to Rio Negro; also southern Brazil. Actually the only Brazilian specimens I have seen are the type and a female from Goias, collected in October I962 at Jatai. I have seen many specimens from Argentina ( 58 우, $33 \sigma^{x} \sigma^{\top}$ ), from the provinces of Salta, Tucumán, La Rioja, Cordoba, Mendoza, Rio Negro, and Buenos Aires; it is also recorded from La Pampa and Chaco.

$V$ ariation. - Common variation in color of the male is summarized in the above description. A few males have the abdominal banding reduced, and some have the prothoracic band and the markings on the legs reduced; two males from Mendoza are all black except for the large scutellar-metanotal spot and some yellow on the outer orbits. These males may mimic a different member of the occidentalis complex (scutellaris White?) just as the red-headed males (also prevalent in Mendoza) may mimic ruficeps Schrottky.

Austrochares exiguus (Banks) new combination

Batazonus exiguus Banks, 1947, p. 380 [Type: ô, BRAZIL: Vista Alegre,

Rio Branco, 6 Sept. 1924 (J. Bequaert) (Mus. Comp. Zool., no. 26781)].

This species is still known only from the type, which differs but slightly from mexicanus and from the more extensively maculated males of gastricus. The late R. R. Dreisbach made a balsam mount of the genitalia some years ago, but the genitalia were mutilated and cleared too long in potash, so it is difficult to prepare a sketch or to make a detailed comparison with related species. The genitalia appear to be much like those of gastricus except that the aedoeagus is more slender and parallel-sided, the digiti more acute apically.

\section{Austrochares mexicanus Dreisbach}

Austrochares mexicanus Dreisbach, 1966, in Evans, 1966, p. 201 [Type: $q$, MEXICO: Minatitlan, Veracruz, 26 Aug.-1 Sept. 1961 (Dreisbach) (Mich. State Univ.)].

This species is known from a short series of both sexes from the type locality and one female from Chiapas. I have seen no additional specimens since the description. The differences from related species are adequately summarized in the keys; the genitalia (Evans, I966, fig. 38) differ only slightly from those of gastricus. The males undoubtedly mimic Mexican members of the Polybia occidentalis complex, while the females bear a strong resemblance to such common pompilids as Sericopompilus neotropicalis and Anoplius apiculatus. 
BANKs, N.

\section{REFERENCES}

1947. Studies of South American Psammocharidae. Part II. Bull. Mus. Comp. Zool. Harvard, 99: 371-486.

BEQUAERT, J.

1944. The social Vespidae of the Guianas, particularly of British

BERG, C.

Guiana. Bull. Mus. Comp. Zool. Harvard, 94: 249-304.

1881. Entomologisches aus dem Indianergebeit der Pampa. Stettin.

Ent. Zeitschr., 42: 36-72.

Brèthes, J.

1909. Himenópteros de Mendoza y de San Luis. Anales Mus. Nac. Buenos Aires, 17: 455-463.

1913. Himenópteros de la America Meridional. Anales Mus. Nac. Buenos Aires, 24: 35-166.

BURMEISTER, $\mathrm{H}$.

1872. Uber die Pompiliden und Sphegiden des La Plata-Gebietes. Stettin. Ent. Zeitschr., 33: 230-241.

Evans, H. E.

1966. A revision of the Mexican and Central American spider wasps of the subfamily Pompilinae (Hymenoptera: Pompilidae). Mem. Amer. Ent. Soc., no. 20, 442 pp.

1968. Studies on neotropical Pompilidae (Hymenoptera). IV. Examples of dual sex-limited mimicry in Chirodamus. Psyche, 75: 1-22.

HAUPT, H.

1950. Pompilidae (Hymenoptera Sphecoidea). Explor. Parc Nat. Albert, Mission de Witte, 69: 1-63.

Holmberg, E. L.

1881. Sobre las especies Argentinas del género Pompilus. Anales Soc. Cient. Argentina, 12:131-144, 273-280.

1903. Delectus Hymenopterologicus Argentinus. Anales Mus. Nac. Buenos Aires, (3) 2: 490-503.

ReED, E. C.

1894. Entomolojia Chilena. Anales Univ. Chile, Santiago, 85: 599-653. SPINOLA, M.

1851. Orden VII. Himenópteros. In Gay, C., Historia de Chile, Zool., v. 6 , pp. 153-568.

TASChenBerg, E.

1869. Die Pompiliden des Museums der Universität zu Halle. Zeitschr. Gesammt. Naturwiss., 34: 25-75. 

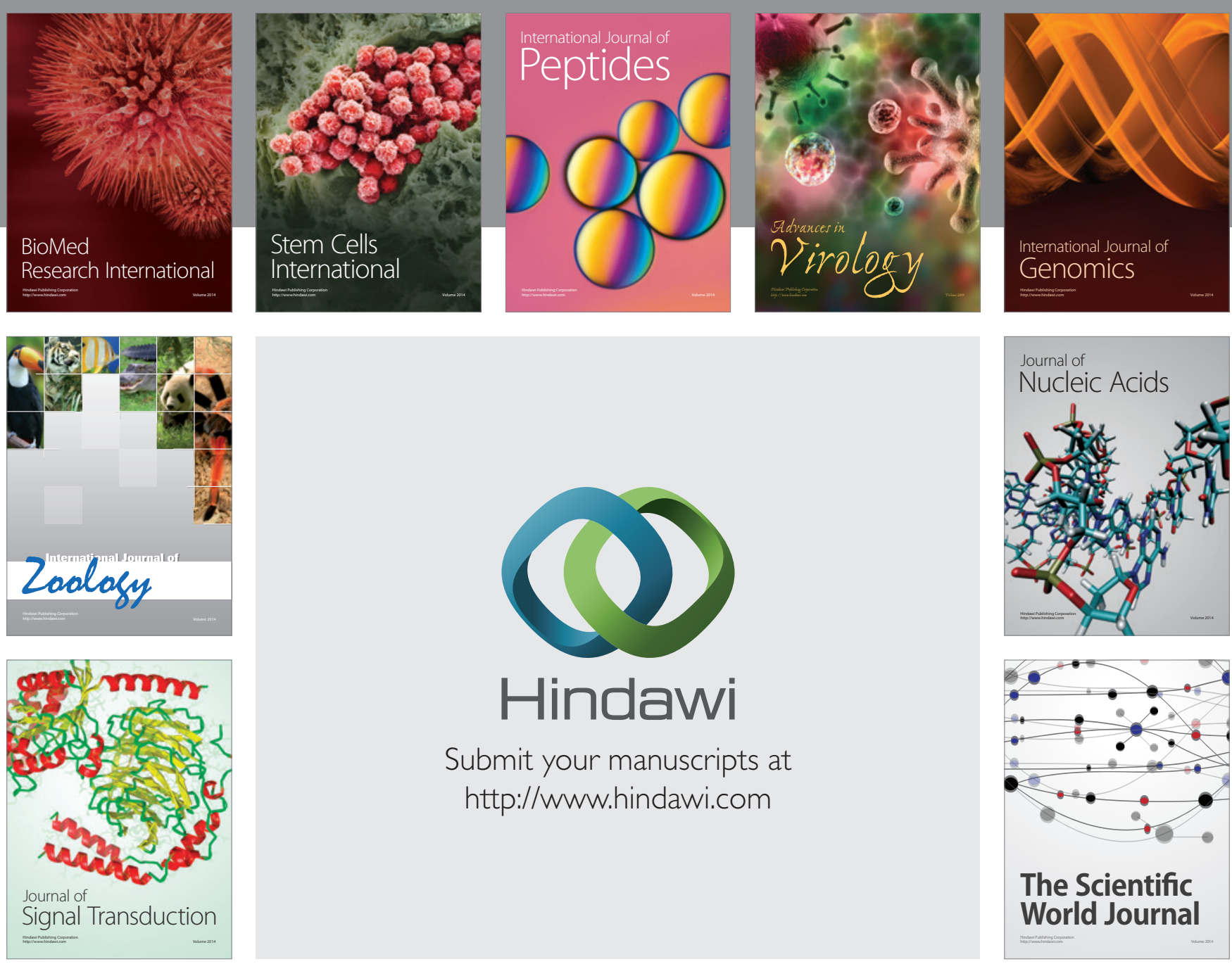

Submit your manuscripts at

http://www.hindawi.com
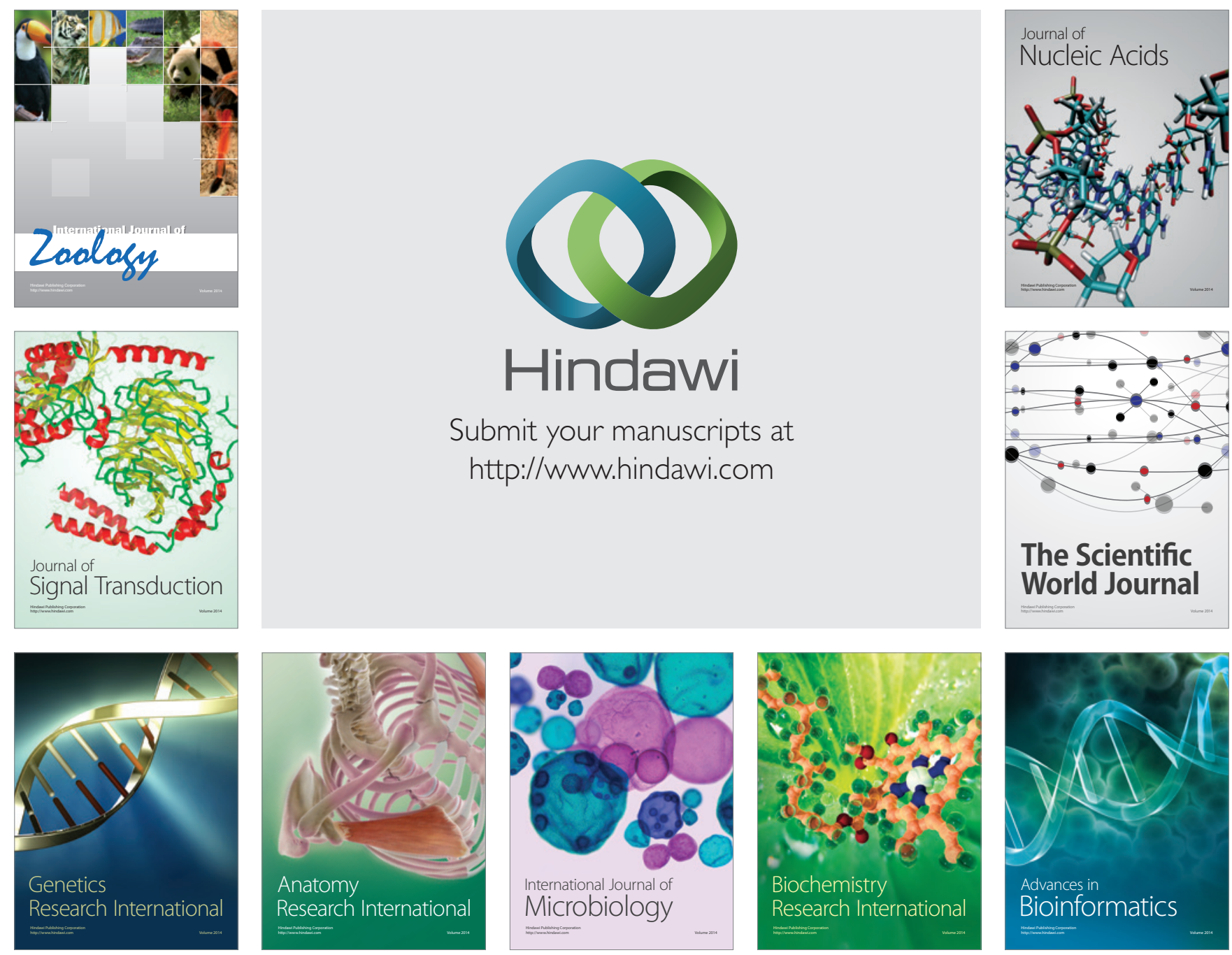

The Scientific World Journal
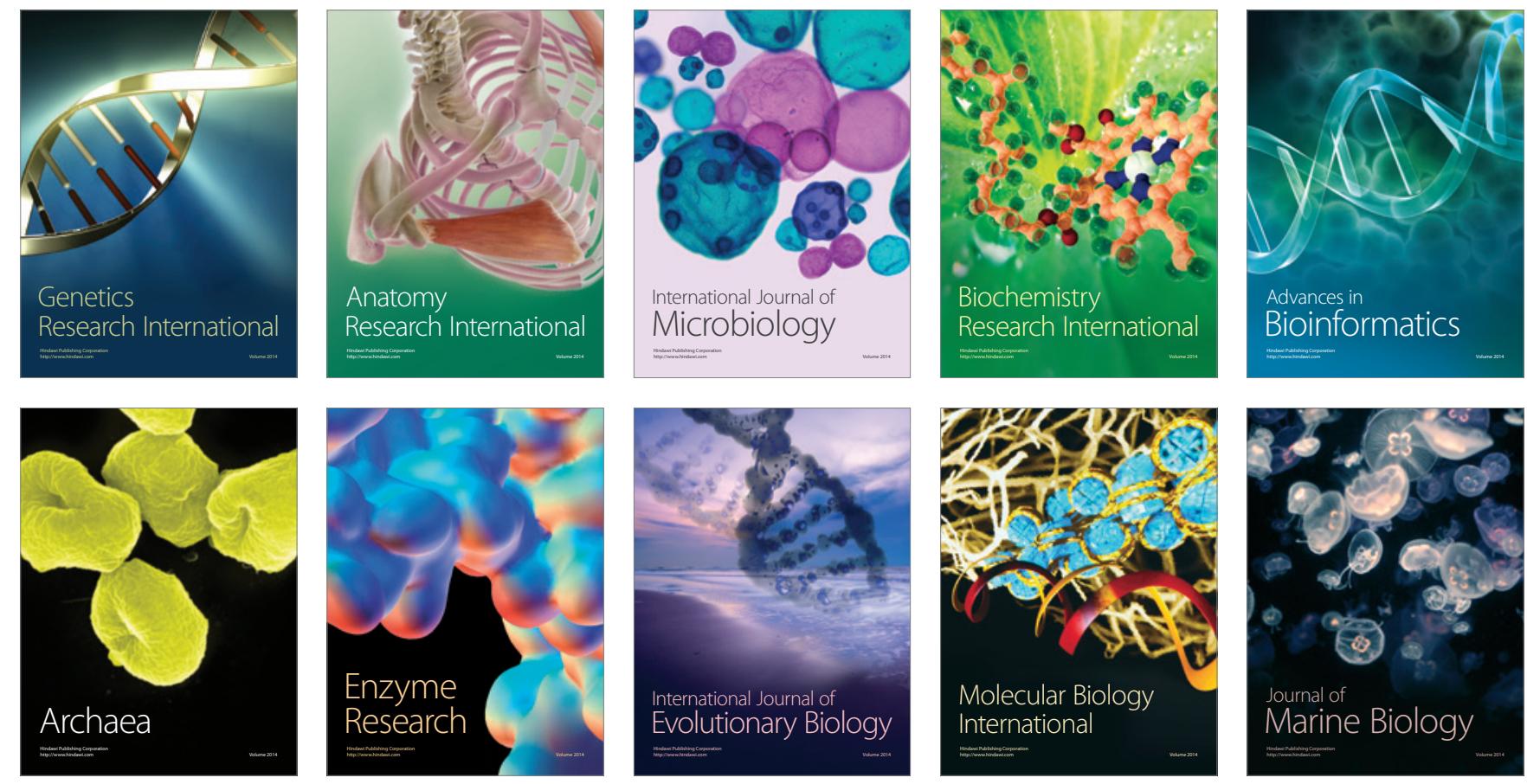